\title{
Students Perspective Towards Writing Descriptive Text On Instagram Post
}

\section{Widi Syahtia Pane ${ }^{1}$, Jordy Angga Kristian ${ }^{2}$}

Universitas Widyagama Mahakam, Indonesia

Email: widi.pane@gmail.com; jordyangga13@gmail.com

\begin{abstract}
Using "Instagram" as a learning medium is an easy way to help students learn descriptive text. Instagram can be a fairy of inspiration that serves as a driving force for student in writing. This research is limited on perspective of students in writing descriptive text on Instagram. The subject of this reserach is XI IPA 1, XI IPA 2, XI IPA 3, XI IPS 1, XI IPS 2 in SMA Negeri 1 Linggang Bigung, the subjects 33 students who makes a descriptive text caption on Instagram post. In this research the researcher employs a qualitative approach in this research qualitative data collecting in this research. The research instrument is an interview (in-depth interview). The theory triangulation technique is carried out in testing the validity of the data using more than one perspective in discussing the problem research, so that they can be analyzed and more complete can be drawn comprehensive conclusions. The interview results show a good respond. According to the findings of the interviews, the majority of students are enthusiastic about using Instagram to study English. Students find that social media Instagram helps them to self expression The results are also strengthened by the results of the other in-depth interviews question number 10. It was shown that all students had positive perceptions toward using Instagram writing descriptive text the purpose of this research is to determine students" perspective towards writing descriptive text on Instagram post. the researcher hopes that this research can be continued by other researcher to research deeper into this research.
\end{abstract}

Keywords: students perspective, descriptive text, Instagram post

DOI

\begin{tabular}{|l|}
\hline Received \\
\hline Accepted \\
\hline Published \\
\hline
\end{tabular}

Copyright and License

\section{: $\quad 10.24903 /$ bej.v4i1.860}

: February 2022

: $\quad$ February 2022

: February 2022

Authors retain copyright and grant the journal right of first publication with the work simultaneously licensed under a Creative Commons Attribution 4.0 International License that allows others to share the work with an acknowledgement of : the work's authorship and initial publication in this journal.

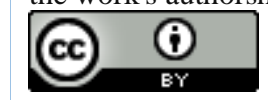




\section{INTRODUCTION}

Using "Instagram" as a learning medium is an easy way to help students learn descriptive text. Instagram can be a fairy of inspiration that serves as a driving force for student in writing. This research is limited on perspective of students in writing descriptive text on instagram. The subject of this reserach is XI IPA 1, XI IPA 2, XI IPA 3, XI IPS 1, XI IPS 2 in SMA Negeri 1 Linggang Bigung, the subjects 33 students who makes a descriptive text caption on Instagram post. In this research the researcher employs a qualitative approach in this research qualitative data collecting in this research. The research instrument is an interview (in-depth interview). The theory triangulation technique is carried out in testing the validity of the data using more than one perspective in discussing the problem research, so that they can be analyzed and more complete can be drawn comprehensive conclusions. The interview results show a good respond.

According to the findings of the interviews, the majority of students are enthusiastic about using instagram to study English. Students find that social media instagram helps them to selfexpression The results are also strengthened by the results of the other in-depth interviews question number 10. It was shown that all students had positive perceptions toward using instagram writing descriptive text the purpose of this research is to determine students" perspective towards writing descriptive text on Instagram post. the researcher hopes that this research can be continued by other researcher to research deeper into this research.

Using "Instagram" as a learning medium is an easy way to help students learn descriptive text. "Instagram" is used to share moments such as photos and videos, and descriptive text is text that contains a factual description of the subject. By using "Instagram" as a learning medium, teachers can manage to teach descriptive text more easily. In addition, they will be more interested in learning English (Soviyah \& Etikaningsih, 2018). Handayani (2016) describes several activities that can be reflected in writing. The first is "caption it". Instagram can be a fairy of inspiration that serves as a driving force for student in writing. As part of this exercise, teachers and students can post interesting photos and descriptive captions in the comments column.

The advantage of this activity is that pictures and photos can help students to get ideas about what they want to write. It becomes a challenge when the researcher asking students to write their signature using sentence types, different sentence types, clauses, prepositional 
phrases, and current vocabulary. The reason for doing this research because researcher wants to know student's perspective 'writing descriptive text on Instagram in SMA Negeri 1 Linggang Bigung and advantages and the disadvantages of using Instagram as a media for learning and to elaborate student's perspective in writing descriptive text using Instagram.

\section{METHODOLOGY}

The researcher takes a qualitative technique in this study. According to Franke, Wallen, and Hellen (2012), qualitative research investigates single person, group, or noteworthy example in order to produce interpretations for the unique occurrence or to provide meaningful generalization. Qualitative research is a appropriate method to learn about people's perceptions and social contexts. According to Mack (2005), "qualitative research is especially effective in gathering culturally unique information on the values, perspectives, activities, and social circumstances of certain people." The descriptive qualitative approach was employed by the researcher in this research. A qualitative research approach, according to Sugiyono (2017), is "a research method based on postpositiveme philosophy, utilized to evaluate the status of natural objects using researchers as a key instrument." A qualitative approach's purpose is to precisely demonstrate an explanation.

The subject of this reserach is XI IPA 1, XI IPA 2, XI IPA 3, XI IPS 1, XI IPS 2 in SMA Negeri 1 Linggang Bigung, the subjects 33 students who makes a descriptive text caption on Instagram post. As for the reason for choosing SMA Negeri 1 Linggang Bigung as the subject of research is because the researcher wants to know students' perspective writing descriptive text on Instagram, that had The researcher identified 33 students who had been followed on Instagram by the researcher based on purposive sample who create a descriptive text caption on an Instagram post. Creswell (2003, p. 185) defines "purposeful" as "the selection of locations or 23 persons that assist the researcher appreciate the problem and the study topic; they must be prepared to reflect on and share this information."

The research instrument is an interview (in-depth interview). According to Bungin (2010) in depth interview method is the same as other method, it's just that the role of the interviewer, the aim of the interview, the informant's function, and the method of interviewing exist they are different. Another interview method consists of the fact that indepth interview with informants as the investigation site were carried out many times and lasted a long time, this situation never happened in total interviews (Bungin, 2010). Interviews can be characterized as methods of communication between the interviewer and the interviewee in order to elicit the interviewee's thoughts on the subjects. 
According to Sugiyono (2012) this implementation is freer than Interviews that are structured. The goal of this style of interview is to identify problems more freely and to provide solutions also get opinions from the sources in them. When conducting interviews, researchers use the help of an interview guide to simplify and focus the questions to be asked. The interview guide discussed after a systematic collective memory analysis. The researcher used semi-structured interview with a purpose to achieve clean and valid data due to the fact it is able to discover and make clear further information on how the participants responded to the analyzed topics.

This research use interview to collecting data, interviewee is an activity that involves both the interviewer and the interviewee. The interviews had been conducted via WhatsApp phone call. The researcher chose 33 students from fifth class XI IPA and IPS based on students who wrote descriptive text on Instagram. Steps in conducting interviews, first the researcher determines the interview question, and then specify the interviewee 33 students from fifth class. The third, provides several questions for the interviewee After getting the answer, then thanking the interviewee for being willing to follow, finally the researcher wrote down all the answers into a transcript.

The researcher in this study used descriptive analysis to examine the data. According to Moleong (2001), data analysis is the act of arranging and categorizing data into patterns, classifications, and essential description units so that it may be decided hypothetically operate as indicated by data. Data analysis would be achieved by compiling data, connecting data, and analyzing data, data, reducing data, presenting data, and drawing conclusions.

In this research, researcher use theory triangulation the theory triangulation technique is carried out in testing the validity of the data used more than one perspective in discussing the problem research, so that they can be analyzed and is more complete can be drawn comprehensive conclusions.

\section{FINDINGS}

The research question analysis was designed to address research questions concerning students' opinions of Instagram as a platform for learning to write descriptive language. As research subjects, the researcher interviewed 33 students from the fifth grade. The interviews were based on an interview outline that included 10 topic-related questions. Questions were posed to participants about their attitudes about writing descriptive text on Instagram posts. The topic of the interview was the focus of the analysis. The issue is the participants' perceptions about writing descriptive text on Instagram. 


\subsection{Analysis of Interview}

In this section, the researcher elaborated the data analysis from the interview. All of questions in these interviews were related to student perspective towards writing descriptive text on Instagram. This research shows participant perspective in used Instagram, based on the interview, how long they used Instagram and how many hours per day they use Instagram, advantages and the disadvantages, the researcher found that the results were varied. Moreover, to gain deeper information and easier, the interview was carried out in bahasa by the researcher.

From 33 participants, all of them used Instagram, they used those Instagram since several years, according to all participant they often used Instagram, about 1 hours to 7 hours a day, from all participants they use Instagram more than 2 years. According to the explanation above, all participants are Instagram active users. Instagram has been used for more than three years.

Students spend more than one hour a day used Instagram. Most of them have no motivation to use Instagram, their motivation is only for entertainment, get rid of boredom also their motivation in used Instagram for self expression like upload some photos getting information and also. To summarize, the motive of the participants used Instagram is only to entertainment. They are motivated in used Instagram for entertainment, self-expression. As stated by Participant 7 and 2:

“there's no motivation, just for entertainment, maybe media for self expression, like sharing our photos or favorite things" Q5 "get rid of boredom, and to spend time in spare time" Q5

The advantages and the disadvantages of Instagram from the point of view of participants show the positive and negative effects of the Instagram application. All of participant stated that Instagram have negative and positive impact. Some participant she stated that Instagram had disadvantages where there is too much information inside it therefore participant is little bit confused to get the correct information and other participant stated that they had disadvantages on network problem only different from other participants they stated that the advantages of used Instagram is can make new friends, help to write descriptive text and also help them to get an up to date information. 
From three participants they stated that disadvantages is only forgetting the time. As stated by participant 1 and 3:

\section{Participant 1:}

"There are some disadvantages, because there's too much information in it so it's a bit confusing, but if open it, I mean exploring, you can get the right information",

Participant 3

"the advantages are being able to have many friends, the disadvantages are none" Q6

As a result of this finding, it is possible to conclude that the benefits of Instagram are dependent on individual perspective. Some participants regard Instagram as a repository for knowledge, while others see it as a communication and learning tool. However, there are certain drawbacks, such as forgetting the time and finding it difficult to filter the information. All participants enjoyed using Instagram to study descriptive text writing, but they have various perspectives on how social media functionalities affect their descriptive text learning process. The first participant notices that Instagram is not too supporting the descriptive text learning. It is different from other participant, she said it was quite helpful help them for learning and getting information and learning.

Participant 3

“very helpful in my opinion” $Q 7$

“yes, I really enjoy it” $Q 8$

Participant 4

"I think Instagram and the internet really help me to learn" $Q 7$ “yes I really like it" $Q 8$

To summarize, the researcher notice Instagram is an interesting medium for writing descriptive prose and for participants to learn and gain knowledge, but not everything on Instagram can be utilized to learn, according to the first participant. The limitations, problems, and consequences that the study subject encountered while using Instagram to practice descriptive writing. According to the interview result all participant 
have different perspective about limitation of used Instagram for descriptive text writing.

14 participant stated that she had network problems when used Instagram.

Different from other participant, they had no any obstacle during use Instagram. The impact that participant perceive during use Instagram for learning descriptive text they have same perspective that give positive impact for them because its help they to learn and improve writing descriptive text in a fun way. According to the statement above, there are no substantial constraints that the entrant faces. in used Instagram. some participant had a limitation from network problem, but the other participant had no difficulty toward descriptive writing through Instagram post

\section{DISCUSSION}

This These chapter summarizes the research outcomes from fifth class XI IPA and IPS from 33 students in SMA Negeri 1 Linggang Bigung. In this research the researcher used the major data collecting approach is in-depth interviews. Based on the interview findings, the researcher expounded on the key point in this section to answer the research question. as stated by from 33 participants, interview results show a good respond. According to the findings of the interviews, the majority of students are enthusiastic about used instagram to study English. Students can use instagram for a variety of purposes. Students find that social media instagram helps them to self-expression.

According to Alhabash, S., and Ma (2017), Instagram is a popular smartphone application that authorize users to take images, apply filters to them, and share them on the site. Most of students respond that instagram help them in learning English especially writing descriptive text. As stated by Wiktor (2012) in chapter two, in terms of language skills, Instagram had the potential to be a language learning tool. All of students learn writing descriptive text on Instagram because can learn in a fun way. All of students agreed that social media instagram facilitated them in learning. In accessing instagram, furthermore, all of students stated that they used instgram every 1 to 7 hours a day.

Some of them sometimes cannot access Instagram because they have network problem. The period of used Instagram have been in existence through than three years the time frame.

for Instagram daily use over than one hours daily. Instagram allow students to seek information or learning. Most of students used Instagram for entertainment. The results are also strengthened by the results of the other in-depth interviews question number 10. It was 
shown that just all students had positive perceptions toward used instagram writing descriptive text.

They believe that Instagram help them in learning especially writing descriptive text in a fun way also as a media for self-expression, sharing photos. As stated by in chapter two Alkhalim, (2013). Instagram is a platform that might be utilized as educational material, making students more engaged in knowing to use images or videos.

Pictures or photographs are extremely helpful for bringing exterior world inside the teaching and utilizing imagery that make learners' interests more concentrated or engaged in studying. As stated by (hu yuheng, 2014). Instagram is fun and fast share the way people live with friends through a series of pictures. Instagram is a relatively new form of communication users can easily share their updates via fetch photo or video.

\section{CONCLUSION}

The researcher would to make some conclusions in this part. As stated in the opening chapter of this thesis, the purpose of this research is to determine students' perspective towards writing descriptive text on Instagram post. The above discussion had been evaluated the perception from fifth class XI IPA and IPS in SMA Negeri 1Linggang Bigung. Based on the result of chapter IV some conclusion.

All participants perceive that instagram is good for learning writing descriptive text, because helpful and fun way to learn descriptive text. All participants enjoy experience used Instagram for descriptive writing. Instagram had the both benefits and drawbacks The benefits of using Instagram are that it is useful for gathering information, it is simple to use, and it aids in the learning process. Instagram's drawbacks include is time consuming, difficult to filter the information.Instagram had the limitation. The limitation is only the network sometimes had problems.

\section{REFERENCES}

Alhabash, S., and Ma, M. (2017). A Tale of Four Platforms: Motivations and Uses of Facebook, Twitter, Instagram, and Snapchat Among College Students? SAGE Journals, $3(1), 1-13$.

Alkhalim. (2013). Penerapan Media Gambar atau Foto dengan Metode Diskusi untuk Meningkatkan Hasil Belajar Siswa Kelas X pada Mata Pelajaran Ekonomi Pokok Bahadan Uang di SMA Negeri 4 Sidoarjo. Jurnal Pendidikan Ekonomi (JUPE). 1(3). Retrieved from http://jurnalmahadiswa.unesa.ac.id/index.php/jupe/article/view/3744

Bungin, B. (2010). Penelitian Kualitatif: Komunikasi, Ekonomi, Kebiakan Publik, Dan Ilmu Sosial Lainnya. Cetakan ke-4. Jakarta: Kencana Prenada Media Group. 
Fraenkel, J. R., Wallen, N. E., \& Hyun, H. H. (2012). How to Design and Evaluate Research In Education (8th ed.). New York, NY: McGraw-hill.

Handayani, F. (2016). Instagram as a Teaching Tool? Really?. International Seminar on English Language and Teaching. 320-328. Retrieved from http://ejournal.unp.ac.id/index.php/selt/article/download/6942/5476 methods sourcebook. 3rd. Thousand Oaks, CA: Sage.

Moloeng, Lexy J. 2007. Metode Penelitian Kualitatif. Bandung. PT. Remaja Rosdakarya.

Mack, N., Woodsong, C., MacQueen, K., Guest, G. and Namey, E. (2005) Qualitative Research Methods: A Data Collector's Field Guide. Family Health International (FHI), USA.

Slameto. (2010). Belajar dan Factor-Faktor yang Mempengaruhinya. Jakarta : Rineka Cipta

Soviyah, S., \& Etikaningsih, D. R. (2018). Instagram Use to Enhance Ability in Writing Descriptive Texts. Indonesian EFL Journal, 32. https://doi.org/10.25134/ieflj.v4i2.1373

Sugiyono. (2017). Metode Penelitian Kuantitatif dan Kualitatif, dan R\&D. Bandung: Alfabe 